\title{
COST METHOD EFFECTIVENESS ANALYSES CASE STUDY - FIXED TELECOMMUNICATION IN ALBANIA
}

\author{
Brikena Tolli \\ Marin Barleti University, Tirana, Albania \\ brikenatolli@gmail.com
}

\begin{abstract}
The fundamental problem in the Telecommunications market, which contributes to slowing down the competition, reclines in the local and central necessary network access, capable to offer regulated services. In order, to overcome to stimulate competition in the telecommunications market effectively, the European Commission intervened with a series of directives forcing the only notable operators who own the network, to provide regulated access. This regulation was then extended to all of the operators with the significant market power. The national regulatory authority is the authority that determines the right access price to encourage downstream competition and at the same time encourage the prospects of new operators to build their own infrastructure. Different methodologies are used to allocate costs for calculating access prices by national regulatory authority in European countries. They use accounting methods, preferring them over what economic theory advises, however these methods are affected by a variety of limitation. The telecommunications sectors in Albania comprise a similar situation that deserves the attention of operators, regulators and academics. This sector is subject to ex ante regulation and access regulation is of public interest. It is therefore of strategic importance to find the right balance between promoting competitions in the short term - allowing new operators to enter in the market - and promoting long-term competition through appropriate incentives to invest in alternative infrastructure. The research is based in qualitative method. There is no information on the costs of operators and their calculations but a qualitative analysis of the collected facts as well as a qualitative analysis of the author based on her background. Primary sources are obtained from documents published by the regulator and operators, legal and sub-legal acts; secondary data are collected from various scientific and professional articles and publications of academics and researchers, also books and regulatory documents of other countries. Electronic and Postal Communications is the Albanian regulator Authority that verifies the compliance of the regulated rates with the method and conditions set for the regulation of the rates. Even though since 2010 the Albanian regulatory has formally accepted the application of the Bottom-up Long-Run Incremental Cost method, it continues to apply a Benchmark model with reference to the rates calculated by the regulators of the Body of European Regulators for Electronic Communications countries. So there has been no evidence of data being used to do a complete research in order to decide whether the results obtained by using the Benchmark model would have been more / less consistent and more / less efficient than those obtained from using the Bottom-up Long-Run Incremental Cost model (cost-oriented model). The author concludes that the regulatory complies with the requirements of the law, but with limited application, it implements the minimum / maximum average rate model of Body of European Regulators for Electronic Communications countries with a gradual correction (glide path). The implementation of bottom-up LongRun Incremental Cost method would be the best way to reduce the fixed network termination/transition rates thus promoting competition. The regulatory should carry out a full study on the calculation of termination/transition rates according to the pure Bottom-up Long-Run Incremental Cost method and also should prepare a manual of procedures for operators with significant market power on how to identify their costs.
\end{abstract}

Key words: Telecommunication, interconnection rates, cost methodologies, BULRIC, AKEP

\section{Introduction}

The majority of European Countries have managed the services of the network industries under a monopoly regime. In particular, referring to the telecommunications market, technological development - especially of microelectronics, information technology and with the introduction of optical fibre - has had a significant impact on the reduction of average production costs, on the exhaustion of economies of scale in some stages of the production chain and consequently barriers to entry in the market have been reduced. Therefore, the conditions were created to be able to introduce competition also in this sector. The European Commission has been the great promoter of radical changes. In order to be able to stimulate competition in the telecommunications market 
effectively, the EC intervened with a series of directives forcing the only historical operators who own the network, to provide regulated access. The obligation to give access is underlined by the fact that the refusal of access constitutes an abuse of a dominant position according to art. 102 of the TFEU ${ }^{1}$. The Commission also encouraged member states to set up national regulatory authorities, legally separated from both telecommunications providers (avoiding the capture of the regulator by the letter) and from the government, with the power to set tariffs and monitor the situation of the entire telecommunications sector. It is the responsibility of the regulatory sector to sets the right access price.

In Albania, the Tlc sector is regulated by the Electronic and Postal Communications Authority (AKEP), which operates under the law no. 9918 dated 19.05.2008 "On Electronic Communications in the Republic of Albania" which sanctions the duties and responsibilities of AKEP in Article 7, 8, and 9. This paper aims to bring the author's critical perspective to the methods of setting fixed network interconnection rates used by the regulator in the regulated markets.

The limits of this paper refer to: low number of interviews; small number of consulted documents; limited number of parameters obtained in the analysis that might affect the quality and competitiveness of the operators. The author encourages all academics and researchers in the field to expand their research beyond the limits recognized by the author in this paper.

\section{Literature Review}

In the early stages of liberalization, ex-ante regulation was indispensable for opening up the market, while ensuring that new entrants were not penalized by the benefits that incumbents enjoyed. It falls under European Commission to issue the directives as guidelines for the regulation to which the Tlc markets are subject at the European level. Obviously, the regulation also called asymmetric regulation must last until disparities in the market are eliminated, that way not supporting the survival of an inefficient operator in the market. (Martellini, 2007).

Access regulation is in itself a bit ambiguous as it reduces the entry barriers for new entrants, allowing them to use the network of the former monopolist, thus increasing competition. One the other hand, it reduces incentives to build an alternative infrastructure similar to the former monopolist by sacrificing dynamic efficiency. Hence, there is a tension between promoting downstream competition through regulating upstream access, and competition between upstream activities. (Hellwing, 2010).

In the Commission's opinion (according to the EC), if access to the network was guaranteed, nothing prevented the market from being competitive ${ }^{2}$. According to the directive ${ }^{3}$, companies with significant market power are obliged to provide access to a cost-oriented regulated price (according to the principle of transparency, nondiscrimination and equity). It is up to the regulator to set the right access price to encourage downstream competition and in the same time encourage the prospects of new operators to build their own infrastructure. The right price must not allow an inefficient operator to enter the market and must not allow the incumbent operator to squeeze the profit margins of the equally efficient new operators, excluding them from the market. The Commission directives require that interconnection and access rates should be based on costs, leaving a fair return on the capital invested, but not specifying the methodologies for calculating these costs or the level of fair return. (Gual \& Jòdar-Rosell, 2009).

Different methodologies for allocating costs to calculate access prices are used by European countries which still remain unaligned ${ }^{4}$. According to economic theory, there are two schools of thoughts to determining network

1 Official Journal of the European Union. Consolidated versions of the treaty on European Union and The treaty on the functioning of the European Union (2008/c 115/01), Article 102.

${ }^{2}$ Directive 97/33 / EC of the European Parliament and of the Council of 30 June 1997, on the interconnection in the telecommunications sector and aimed at guaranteeing universal service and interoperability through the application of the principles of supplying an open network (ONP) .

${ }^{3}$ Directive 2002/19 / EC of the European Parliament and of the Council, of 7 March 2002, relating to access to and interconnection of electronic communications networks and related resources (access directive). Art. 1

${ }^{4}$ Brussels, 12.11.2018 SWD(2018) 463 final Commission Staff Working Document Evaluation Report on the Commission's 2009 Recommendation on Termination Rates (Recommendation 2009/396/EC) 
access prices that take economic principles into account, namely, "the efficient component pricing rule - ECPR ${ }^{5}$ and the approach evoked by the Ramsay ${ }^{6}$ principle. However, regulators have preferred to focus on the use of accounting methodologies to solve the problem, by neglecting the considerations related to market demand and supply. Among the methods mainly used by the Tlc sector regulators, we can name the following:

- The first is the method of fully distributed costs (FDC). It takes into account all the costs incurred by the company. The total cost attributed to the access network, and also the price, is equal to the sum of costs directly attributed to each component of the network and the fraction of the common costs attributed to each component. Similarly, the access price is also calculated as the sum of the prices of each component. (Marzi et al., 2001).

- The second is the long run incremental cost (LRIC) method ${ }^{7}$. It is the method of use, which the Commission recommended in the 2002 directives, in order to eliminate the inefficiencies of the former monopolist. It is not based on the historical costs of the former monopolist company, but on the costs of an alleged efficient new operator who uses the most efficient technology of the moment to produce the same services as the former monopolist. For the calculation of these costs is used the randomness criterion, which relates the cost to the reason itself. This method is based on current costs where the network components are valued at fair value.

- The third is the Retail method - minus a form of ECPR. According to this methodology, the access price is imposed equal to (1-x) \% of the retail price. The incumbent is free to set the retail price and consequently the upstream access price is fixed by subtracting the avoidable costs (CE) incurred by the incumbent from the retail price. By definition, this method is not cost-oriented ${ }^{8}$.

However, in recent years it can be seen that the regulation of voice termination in fixed networks has led to a marked general decline in tariffs, although this is less than the decline in tariffs in the mobile network sector ${ }^{9}$.

\section{Methodology}

Methodology of the research is composed of following steps:

Sampling (limited number of operators as well as regulators);

$>$ Qualitative research method (in the paper there is no information on the costs of operators and their calculations but a qualitative analysis of the collected facts as well as a qualitative analysis of the author based on his background.)

$>$ Data: (primary sources are obtained from documents published by the regulator and operators, legal and sublegal acts; secondary data are collected from various scientific and professional articles and publications of academics and researchers, books and documents of regulators of other countries)

\section{Findings, Analysis and Discussions}

The sample created for the purpose of the study consists on the operators in the telecommunication sector, the number of which is limited in Albania. The data and reports taken into account are collected from Albtelekom, Telekom Albania and Vodafone Albania.

\footnotetext{
${ }^{5}$ Considering a liberalized market where the incumbent is integrated vertically, this rule starts from the assumption that the retail price is fixed in advance by the regulator. At this point, the access price will only affect production efficiency, i.e. the entry of new operators into the market. The regulator must set an access price that minimizes production costs to achieve production efficiency. (Cambini et al. 2000)

${ }^{6}$ The access price and the retail price of the network owner are fixed simultaneously. This model offers a better solution in the presence of fixed costs by encouraging both the entry of new efficient operators and investments in new infrastructures. Cambini, Ravazzi, Valletti. (2000).

${ }^{7}[. .$.$] The long-term incremental cost is the cost determined by a significant increase in the output produced with the use of the$ most efficient technologies in such a time that all production costs can be considered variable [...]; Resolution no. 258/02 I CONS; Public consultation on the introduction of an incremental cost accounting methodology for notified operators of fixed and mobile networks; Official Gazette of the Italian Republic of 19 August 2002, n. 193

${ }^{8}$ OECD Reports Access Pricing 2004. Access Pricing in Telecommunications. This report on access pricing and the regulation of access services was adopted by the Competition Committee in 2004.

${ }^{9}$ BEREC Annual Reports for 2018, 13 June 2019.
} 
By decision of AKEP No. 74, dated 1.10.2018 "On the approval of the document: regulation of tariffs for SMP entrepreneurs in wholesale fixed network terminating and transit calls" it is specified that such operators as Albtelekom Ltd, Telekom Albania Ltd and 67 other operators are those with significant market power (SMP) in the fixed telephone sector. From the information provided by official publications ${ }^{10}$, Albtelekom is SPM with the following indicators:

- $100 \%$ of the market share of call termination to network subscribers.

- $99 \%$ of the market share for national call volume.

- Revenue from transit of these calls is $90 \%$

In evaluating the SPM, AKEP has considered of great importance the market shares, the countervailing power of service buyers, and the termination service rates. (AKEP Decision No. 21, 2018).

These operators are subject to regulatory measures for the termination and transition service of calls in fix network. The Law No. 9918, dated 19.5.2008 (as amended) "On electronic communications in the Republic of Albania", regulates the promotion of competition and efficient infrastructure in electronic communications through the principle of technological neutrality. The Article 57 of the Law also regulates the methods of setting rates for operators with SPM. AKEP is the regulator defined in this law that verifies the compliance of the regulated rates with the method and conditions set for the regulation of the rates.

The interviews with AKEP officials and the review of public consultation documents published by AKEP show that since 2010 the use of the BULRAIC method for fixed telephony has been formally accepted, whereas for Bit stream access the Retail + method was used until 2016. Since then, this method has undergone a significant change by being replaced by $\mathrm{x} \%$ reduction of the maximum and / or minimum Bit stream access fee. From the interviews with AKEP officials and ex-officials resulted that applying the BULRIC method turns out to be difficult and cost effective, therefore, currently it is used an alternative technique of a rate adjustment according to a Benchmark level and their escalation reduction (glide path).

The data and reviewed literature show that using Retail + allows the SPM operator is free to choose the retail price and as a result, it enables it to control the entire market. The choice of such a retail price enables it to remove competitors from the market or compress their profit margin. AKEP's motivation to have used the Retail + method until 2016 is considered unjustified. The justification for using this method, namely to preserve the relevance of the final prices, which are certainly not under discussion, without however considering whether such relevance would not have been even better assessed by a cost orientation model for all access services.

Even though since 2010 AKEP has formally accepted the application of the BULRIC method, it continues to apply a Benchmark model with reference to the rates calculated by the regulators of the BEREC countries. So there has been no evidence of data being used to do a complete research in order to decide whether the results obtained by using the Benchmark model would have been more / less consistent and more / less efficient than those obtained from using the BULRIC model (cost-oriented model). The glide path is applied to avoid problems to existing market operators and their finances through an abrupt reduction of termination/transition rates that result from the application of benchmarking rates. The use of a Benchmark model, even escalating in time, does not reflect the differences that exist between the BEREC countries and Albania. The Application of Benchmark model would require the calculation of a correction coefficient of the economic characteristics between Albania and the BEREC countries. Among the most notable differences, we can mention:

○ relatively small market compared to most European Community countries;

$\circ$ technological development in the telecommunications sector;

$\circ$ the purchasing power of the final consumer.

Also, the use of the "Glide path ${ }^{11 "}$ of tariffs, although encouraging operators to invest due to a higher return on investment (as long as it lasts), prolongs the inefficiency effects that produce the Benchmark model tariffs. In other words, instead of the AKEP work on the implementation of the BULRIC method of rate setting, it simply

${ }^{10}$ DECISION No. 21, dated 30.3.2018 “On Document Adoption. Market analysis of fixed telephony: Wholesale market in termination/transits call in Public Fixed Telephone Networks, Final Document" and the 2018 Annual Activity Report, AKEP ${ }^{11}$ Malaysian Communications and Multimedia Commission, Review of Access Pricing, Public Inquiry Paper, 6 October 2017 
wastes time in escalating a rate that is inefficiently calculated, thus causing financial harm to key market players and their finances. Combining Benchmark with Glide path, strays further away termination/transition rates from an efficient result obtained using cost-oriented rates.

During 2017-2019, the applied reduction is $23 \%$ and by December 2019, the applied reduction is $46 \%$. The Benchmark level takes into account the average of the maximum/minimum rates level applied by BEREC country regulators including $28 \mathrm{EU}$ countries and 9 other countries in the region. In the market analysis of fixed telephony carried out by AKEP in 2015 (AKEP Decision No. 2617, 2015), it emerges that the average level of the maximum/minimum rates in the BEREC countries is higher than the average rates of these countries referring only to the rates calculated using the Pure BULRIC method. The method of maximum/minimum average rate of BEREC countries remains controversial to be applied by AKEP not only because of the higher rate value this method produces but also because of the fact that rates are not corrected by differences existing between BEREC countries (whose rates are used for Benchmark) and Albania. According to the law no. 9918, dated 19.05.2008, article 57, paragraph 1, iii), AKEP, in setting rates, is obliged to orientate in the determination of rates according to efficient costs that enable a reasonable profit. The application of the LRIC method is entirely in accordance with how it is required from the law. This method would require from AKEP the application according to the graph below ${ }^{12}$ :

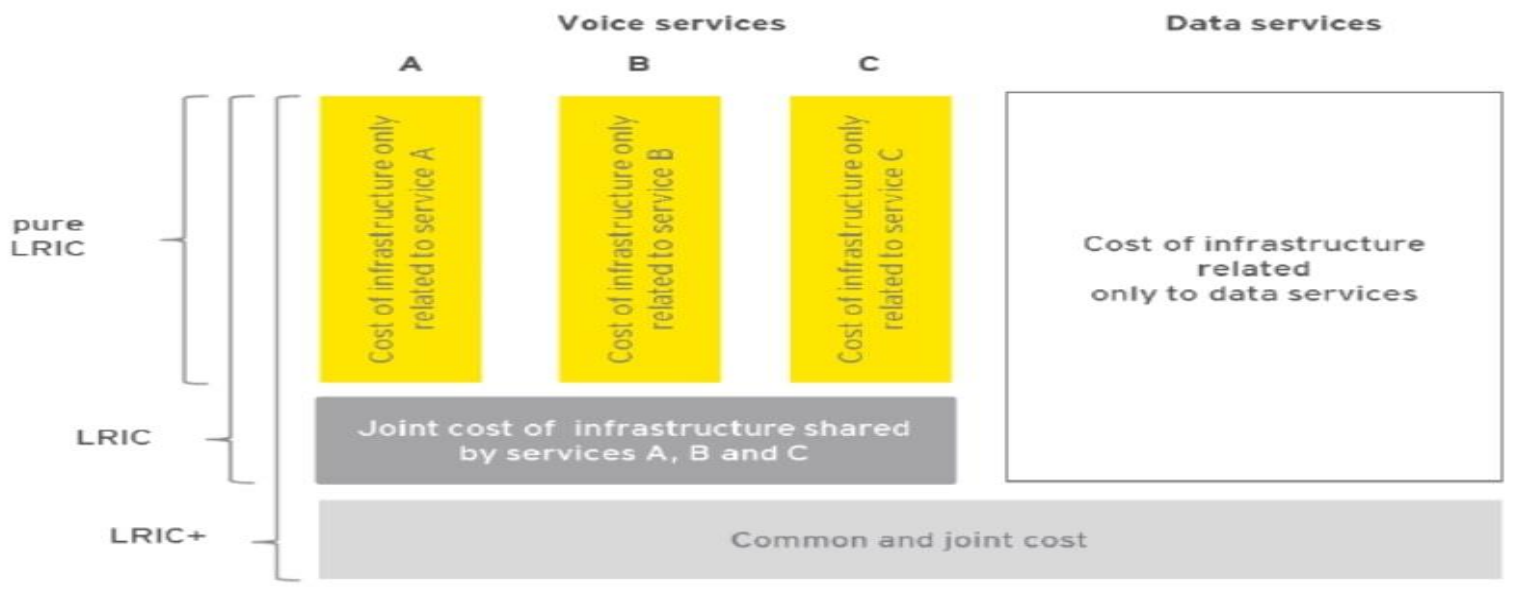

To accurately identify costs, it is required the establishment of the expertise groups (economists and engineers). In their task, these working groups operate in accordance with the Bottom-Up approach of all network costs faced by an efficient operator. This approach provides the following steps:

- Dimension and revaluation of the network;

- Estimation of the network costs;

- Estimation of the non-network costs;

- Estimation of the operating maintenance and supporting costs;

$\circ$ Estimation of the services costs. ${ }^{13}$

It would be cost-effective to invest energy, human resources and financial values in calculating BULRIC costs not only to comply with the law but also with the EU recommendations. It is economically proven that using the BULRIC method leads to the determination of lower rates by:

- Helping to reduce entry barriers for new operators;

- Promoting competition in the wholesale markets;

- Creating an advantage for final consumers.

${ }^{12}$ BU-LRIC methodology, Fixed network, Version 30-09-2015, EY, Building a better working world. 
ISSN 2661-2666 (Online) International Scientific Journal Monte (ISJM) DOI: 10.33807/monte.202004655 Volume 3 No. 1 (2020): April

\section{CONCLUSIONS}

AKEP complies with the requirements of the law, but with limited application, AKEP implements the minimum / maximum average rate model of BEREC countries with a gradual correction (glide path).

The Operators require AKEP to apply for the determination of interconnection rates a cost-based method and specifically the pure BULRIC method. The implementation of this method would significantly reduce the fixed network termination/transition rates thus promoting competition.

Applying this method for AKEP is expensive in terms of logistics, human and financial resources.

\section{RECOMMENDATIONS}

1. AKEP should carry out a full study on the calculation of termination/transition rates according to the pure BULRIC method and also should prepare a manual of procedures for the operators with SPM on how to identify their costs according to the table given on the page 7.

2. The provision of detailed costs by operators with SPM to AKEP's needs would facilitate the application of pure BULRIC model from the AKEP and would reduce the financial burden for applying this method.

3. AKEP should conduct a public consultation with stakeholders on the new rate calculation approach aiming to involve stakeholders in the process. 
ISSN 2661-2666 (Online) International Scientific Journal Monte (ISJM) DOI: 10.33807/monte.202004655 Volume 3 No. 1 (2020): April

\section{References}

AKEP (2018). Raporti vjetor i veprimtarise 2018. Retrived from https://akep.al/wpcontent/uploads/2018/09/AKEP-RAPORT-VJETOR.pdf

AKEP. (2018). Vendim Nr. 21, datë 30.3.2018 Për miratimin të Dokumentit: Analizë e tregut të telefonisë fikse: tregjet me shumicë të terminimit dhe tranzitimit të thirrjeve në rrjetet telefonike publike fikse Dokument përfundimtar. Retrived form https://akep.al/wpcontent/uploads/images/stories/AKEP/publikime/2018/Vendim_nr.21_date_30.03.2018.pdf

AKEP. (2018). Vendim Nr. 74, datë 1.10.2018 Për miratimin e dokumentit: Rregullimi i tarifave të sipërmarrësve me FNT në tregjet me shumicë të terminimit dhe tranzitimit te thirrjeve në rrjetet fikse. Retrived from https://akep.al/wpcontent/uploads/images/stories/AKEP/publikime/2018/Vendim_nr.74_date 1.10.2018_Miratimi_i_dok umentit_final Rregullimi_i_FTR.pdf

AKEP. (2015). Vendim Nr. 2617, datë 8.10.2015 "Për Miratimin të Dokumentit: Analizë e tregut telefonisë fikse: tregjet me pakicë dhe tregjet me shumicë të terminimit, tranzitimit dhe origjinimit - Dokument Përfundimtar" Retrived from https://akep.al/wpcontent/uploads/images/stories/AKEP/GALERI/Vendim-Nr2617date8102015.pdf

BEREC. (2019). Annual Reports for 2018. Retrieved from file:///C:/Users/User/Downloads/8598-berec-annualreports-for-2018 0.pdf

BEREC. (2017). Termination rates at European level July 2017. Retrieved from file:///C:/Users/User/Downloads/7524-termination-rates-at-european-level-july 0.pdf

Cambini C., Ravazzi P. e Valletti T. (2000). La tariffazione dell'accesso nelle telecomunicazioni: Principi economici e interventi regolatori in alcuni paesi industrializzati. Working Papers form ICER. Retrieved from https://www.bemservizi.unito.it/repec/icr/wp2000/Cambini10.pdf

Cambini C., Ravazzi P. e Valletti T. (2000). Regolamentazione e mercato nelle telecomunicazioni. Roma, Italy: Carocci Editore.

European Commission. (2018). Commission Staff Working Document. Evaluation Report on the Commission's 2009 Recommendation on Termination Rates (Recommendation 2009/396/EC). SWD(2018) 463 final. Brussels: European Commission.

European Commission. (2017). Europe's Digital Progress Report 2017. Connectivity. Broadband market developments in the EU. Retrived from file:///C:/Users/User/Downloads/EuropesDigitalProgressReportConnectivityChapter.pgf

EY (2015). Building a better working world. Version 30-09-2015. BU-LRIC methodology, Fixed network. Retrieverd from https://www.gncc.ge/uploads/other/2/2734.pdf

Gazzetta Ufficiale della Repubblica Italiana (2002) Delibera n. 258/02/CONS; Consultazione pubblica sull'introduzione di una metodologia di contabilità a costi incrementali per gli operatori notificati di rete fissa e mobile; Gazzetta Ufficiale della Repubblica Italiana del 19 agosto 2002, n. 19.

Gazzetta ufficiale delle Comunità europee. (1997). Direttiva 97/33/Ce del Parlamento Europeo e del Consiglio del 30 giugno 1997, sull'interconnessione nel settore delle telecomunicazioni e finalizzato a garantire il servizio universale e l'interoperatività attraverso l'applicazione dei principi di fornitura di una rete aperta (ONP).

Gazzetta ufficiale delle Comunità europee. (2002). Direttiva 2002/19/Ce del Parlamento Europeo e del Consiglio del 7 marzo 2002, relativa all'accesso alle reti di comunicazione elettronica e alle risorse correlate, e all'interconnessione delle medesime (direttiva accesso). Art.1.

Gual J. and Jòdar-Rosell S. (2009). European telecoms regulation: Past performance and prospects. in Competition policy in the EU. Xavier Vives. Oxford University press.

Hellwing, M. (2010). Competition Policy and Sector-Specific Regulation for Network Industries', in Completion Policy in the EU, Xavier Vives. Oxford University press 
ISSN 2661-2666 (Online) International Scientific Journal Monte (ISJM) DOI: 10.33807/monte.202004655 Volume 3 No. 1 (2020): April

Ligj Nr.9918, datë 19.5.2008 (I ndryshuar) Për Komunikimet Elektronike në Republikën e Shqipërisë. Neni 7,8,9 dhe 57. In https://akep.al/wpcontent/uploads/images/stories/AKEP/legjislacioni/ligji9918ndryshuar-versioni-publikimweb190313.pdf

Malaysian Communications and Multimedia Commission. (2017). Review of Access Pricing, Public Inquiry Paper. Retrieverd from https://www.mcmc.gov.my/skmmgovmy/media/General/pdf/PI-Paper-Reviewof-Access-Pricing-2017.pdf

Martellini, M. (2007). Dal monopolio alla concorrenza. La liberalizzazione incompiuta di alcuni settori. (pp. 190-240). Milano, Italy: Franco Angeli.

Marzi G., Prosperetti L. e Putzu, E. (2001) La regolazione dei servizi infrastrutturali. Bologna, Italy. Il Mulino.

OECD (2004). OECD Reports. Access Pricing 2004. Access Pricing in Telecommunications. France. Retrieved from http://www.oecd.org/regreform/sectors/27767944.pdf

Official Journal of the European Union. (2008). Consolidated versions of the treaty on European Union and The treaty on the functioning of the European Union (2008/c 115/01), Article 102. 